\title{
Comparison of Service Quality Gaps among Teachers and Students as Internal and External Customers
}

\author{
Rahim Mosahab, PhD Candidate (Corresponding author) \\ School of Management, Universiti Sains Malaysia (USM), Malaysia \\ E-mail: rmosahab@yahoo.com \\ Osman Mahamad, Professor \\ Graduate School of Business, Universiti Sains Malaysia (USM), Malaysia \\ E-mail: osman@usm.my
}

T. Ramayah, Associate Professor

School of Management, Universiti Sains Malaysia (USM), Malaysia

E-mail: ramayah@usm.my

\begin{abstract}
Using an internal marketing (IM) approach, this study aims to compare the quality gap of educational services among students (service customers) and teachers (service providers) at the district 6 public high schools of Tehran, Iran. In a cross-sectional study, the survey questionnaire was completed by two distinct groups of respondents, 230 teachers and 384 students. Findings indicate that there is negative gap in each of the five dimensions among both groups of teachers and students. Quality gaps from viewpoint of both groups were negative. The largest mean quality gap from students and teachers viewpoint was in the responsiveness and tangibility dimensions, respectively. The largest and smallest differences between students and teachers viewpoint were in the responsiveness and tangibility dimensions. The findings show a need for implementation of IM.
\end{abstract}

Keywords: Internal marketing, Internal customer, Service quality, Quality gap

\section{Introduction}

Education costs a lot of money for the government as well as parents and service quality has been receiving much prominence because of its positive relationship to costs (Kellogg et al., 1997). Service quality is also positively associated with financial performance (Hallowell, 1996; Rust et al., 1999), customer satisfaction (Stauss \& Neuhaus, 1997; Soderlund, 1998) and customer retention (Keaveney, 1995). Many Iranian parents pay a large amount of money to register in private schools instead of using free public schools, because they are not satisfied with educational quality in public schools. Quality of education is the main concern of educational organizations and parents, yet based on the literature review to date, empirical study on public quality of education does not exist. Quality of services including education, as one of the most important competitive priority has shifted from the literature of manufacturing strategy to the service arena (Pariseau \& McDaniel, 1997). Accordingly, successful service organizations are the ones who focus on the customers and satisfy their expectations (Juwaheer, 2004).

Quality service is defined as the situation in which the consumer's perception of service performance meets or exceeds their expectation of what the service firm should do. The key to service quality, then, is to meet or exceed consumer expectations. One problem with measuring customers' satisfaction is that there may often be discrepancies between the consumer's viewpoints and the provider's understandings of what constitutes quality service (Pariseau \& McDaniel, 1997). Any differences between consumer viewpoints and the organization's perception of consumer viewpoints on quality are important to identify and determine the level and quality of the service provided (Douglas \& Connor, 2003).

Alternatively, if the gap between providers and consumers are removed, the consequences could be generation of more repeat visits, encouragement of new business through favorable consumer comments leading to increased profits and a positive image for the organization. This would facilitate the development of appropriate managerial quality systems, which should maximize consumer satisfaction (Douglas \& Connor, 2003). For education institutions, students' views cannot be inferred from managers or providers' views, and it is important 
to look at what their students want and not to collect data based upon what the institution perceives its students find important (Oldfield \& Baron, 2000). Therefore, the problems remain on 1) employees' perception of service quality is becoming a challenging issue as perception drive behavior (Steers \& Porter, 1991), and 2) according to Yoo \& Park (2007) among all related researches, not much attention has been paid to employees in light of service quality.

Research into service quality in educational organizations and mostly in higher education context is somewhat scant (Pariseau \& McDaniel, 1997), but, according to the literature study, firstly, none of them has addressed the context of high schools in Iran, and secondly, the previous researches did not have an internal marketing approach to consider employee perception of service quality. Within this context and from internal marketing point of view, the objective of this paper was to determine: a) the level of quality gap perceived by teachers, b) the level of quality gap perceived by students, and c) the differences, if any, between the viewpoints of two groups.

\section{Literature Review}

Service quality: The fact that the quality of the perceived product is becoming the most important competition factor in educational settings as it is in business world has been the reason of naming the present business era as "Quality Era" (Peeler, 1996). Consequently, service marketing intellectuals and researchers have offered several metaphors of this issue. For example, Berry (1988) calls it the most powerful competition weapon and Clow (1993) calls it the organization's life-giving blood. Quality is a multi-dimensional phenomenon, but the role of contact employees has been emphasized the most, and focused repeatedly. Researchers have widely emphasized on employee in different ways such as contact issues (Soteriou \& Chase, 1998), satisfaction (Meyer \& Collier, 2001; Voss et al., 2005), commitment (Farber \& Wycoff, 1991), motivation (Hays \& Hill, 2001), internal marketing (Berry \& Parasuraman) and service quality (Parasuraman et al., 1988).

\subsection{Service quality and service behavior}

The relationship between service behavior and service quality is proving its role and importance, because by effectively recruiting, developing, motivating and retaining the teachers as the main service provider in the educational service organization can assure the quality of educational services (Berry \& Parasuraman, 1991). Several authors (e.g. Berry \& Parasuraman, 1991; George, 1990; Lings, 2000) claim that implementing internal marketing concepts will result in an increase of service quality. The mechanism is that, internal marketing (IM) results in employee satisfaction with his/her job and Locke, defined job satisfaction as: "a general pleasurable or positive emotional state resulting from the appraisal of one's job or job experiences" (Locke, 1976, p. 1300). Job satisfaction is also defined as the general emotional evaluations of service providers for their job situation and job experiences (Brown \& Peterson, 1993). Job satisfaction has a positive effect on the customer (student) orientation of service providers (Hoffman \& Ingram, 1992). It can be the foundation to enhance a positive interaction between service providers (teachers) and customers (students) (Reichheld \& Sasser, 1990). Implementation of IM may result job satisfaction and teachers are likely to exhibit different attitude than those who merely satisfy. Teachers who are committed to a school are more likely to delight and have highly positive attitude lower turnover (Simon et al., 2009).

\subsection{Service quality and employee}

Employees have been widely considered for, responsiveness, empathy and courtesy (Parasuraman et al., 1988), commitment (Farber \& Wycoff, 1991), satisfaction (Meyer \& Collier, 2001; Voss et al., 2005), contact (Soteriou $\&$ Chase, 1998), and motivation and vision (Hays and Hill, 2001). But, according to Yoo \& Park (2007), among all related researches, not much attention has been paid to employees in general and teachers in particular in light of service quality. Schools as educational service organizations have to seek ways to deliver higher quality of educational services to not only keep up with the others but also differentiate themselves from others (Hsieh \& Lin, 2010). Service quality is "a global judgment, or attitude, relating to the superiority of the service" (Parasuraman, Zeithaml, \& Berry, 1988, p. 16). Service has three characteristics: (1) it is physically intangible, (2) it is an activity not a thing, and (3) production and consumption are simultaneous in some manner (Gronroos, 1982).

\subsection{Service quality and IM}

The relationship between IM and service quality lies in the increased emphasis on service quality and its development through IM in customer oriented corporations (Ahmed \& Rafiq, 2003; Rafiq \& Ahmed, 2000). Implementation of IM concept is required in order to align the organization's internal environment with its (external) market objectives (Gounaris, 2008). IM was defined as "viewing employees as internal customers, 
viewing jobs as internal products that satisfy the needs and wants of these internal customers while addressing the objectives of the firm" (Berry \& Parasuraman, 1991, p. 272). Internal marketing is defined as a process to attract, develop, motivate and also retain qualified employees through job-products that satisfy their needs (Berry \& Parasuraman, 1991). Flipo (1986) suggests that IM strategies can be developed as the implementation of the traditional 4 Ps marketing mix, the product as the job, the price as the opportunity cost of engaging in the job, the place as a location where the jobs are offered, and promotion, such as reward and communication.

\subsection{Service quality measurement}

Service quality is determined by calculating the difference between two scores of perceptions and expectations (P-E) where better service quality results in a smaller gap (Landrum et al., 2008). Service quality (SERVQUAL) is the most highly cited and the original of the two instruments created by Parasuraman, Zeithaml, \& Berry $(1985,1988)$. This original instrument measures seven service quality dimensions, and contains 22 items and each subject responds twice to each item, once on perceptions and once on expectations. The SERVQUAL instrument has been the predominant method used to measure consumers' perceptions of service quality. It has five generic dimensions or factors (Parasuraman et al., 1988) and they are stated as follows:

Tangibles - Physical facilities, equipment and appearance of personnel.

Reliability - Ability to perform the promised service dependably and accurately.

Responsiveness - Willingness to help customers and provide prompt service.

Assurance (including competence, courtesy, credibility and security) - Knowledge and courtesy of employees and their ability to inspire trust and confidence.

Empathy (including access, communication, understanding the customer) - Caring and individualized attention that the firm provides to its customers.

Statements (in both the expectations and perceptions sections) are grouped into five dimensions: a) tangibles; b) reliability; c) responsiveness; d) assurance; and e) empathy. Tangibles represent the physical facilities, equipment, and appearance of personnel. Reliability refers to the ability to perform the promised service dependably and accurately. Responsiveness is the willingness to help participants and provide prompt attention. Assurance indicates courteous and knowledgeable employees who convey trust and confidence. The empathy dimension includes caring and individual attention to users (Juwaheer, 2004).

\section{Research Method}

This cross sectional study was carried out in 2009 within the district 6 public high schools of Tehran, the capital city of Iran. Tehran city has 22 educational districts and district 6 located in the central part of the city with middle class residents and moderate income was chosen to have better understanding of public schools educational service quality. Survey questionnaire was completed by two distinct groups of respondents, teachers (providers) with at least 2 years of teaching experience and students (consumers) studying in the last 2 years of high school. The reason behind having 2 years of experience to respond to the questionnaire was because, employment as a permanent teacher requires successfully passing at least two years of testing period. Same way for the students, the high school is a four years period and students choose their branch education after successfully passing of first 2 years. Schools were contacted and cooperative ones were chosen to be investigated, and 384 students along with 230 teachers had been approached to be examined by using simple random sampling procedure.

The survey instrument was designed around the validated SERVQUAL instrument. SERVQUAL, developed by Parasuraman et al. (1985 \& 1988), is an established framework for the measurement of general service quality. This framework has been extensively used and tested across a wide range of public and private sector services, and was therefore chosen as the instrument for the research. The items of original SERVQUAL were modified in English for educational services, and then translated into Farsi. Three experts in the field, reviewed the questionnaire to determine its consensual validity, and the wording of statements was also simplified. Modification of the instrument for different service settings is supported by the developers of the instrument (Parasuraman et al., 1994). Lastly a pilot test was conducted with 25 students and a number of teachers, and final adjustment was made, accordingly. Using Cronbach's alpha coefficient, internal consistency of different items of expectations and perceptions were 0.88 and 0.84 for student questionnaire, and 0.86 and 0.93 for teachers, accordingly. All were above the 0.7 recommended by Nunnally (Nunnally, 1978).

The data collection was self-administered, and five undergraduate students were used to deliver questionnaires to the selected respondents. Students were given verbal and written instructions, and completed the sample questionnaires before distribution in order to be able to respond to any possible questions by participants. The Mann-Whitney test was chosen to test differences in means of the two populations. The data collection 
instrument consisted of two sections. An expectations section consisting of 22 statements and a perceptions section consisting of a matching set of statements. A five-point Likert scale ranging from strongly agree to strongly disagree was used to measure the students and teachers expectations, and the same scale ranging from strongly agree to strongly disagree was used to measure expression of their perceived experience on each aspect of service.

Service quality gap was measured by computing the difference between the rating respondents assigned to expectations and perceptions statements $(\mathrm{QG}=\mathrm{P}-\mathrm{E})$. Accordingly, a negative quality gap score was gained if the students and teachers expectations passed their perceptions; a positive quality gap score was gained if the perceptions exceed exceptions. If perceptions and expectations were equal, there was no quality gap. Statistical significance was considered achieved with $\mathrm{p}$ value of less than 0.05 .

\section{Findings}

From total of students who completed the questionnaire, 268 students ( 67.1 percent) were boys and the rest were girls, and 161 teachers (70 percent) were males and the rest were females. Table I shows that the mean quality gaps from point of view of both groups in all the dimensions were negative. From students' viewpoint the largest mean quality gap was in the responsiveness, followed by empathy, assurance, tangibility and reliability dimensions. Teachers stated that the largest mean quality gap was in the tangibility, followed by assurance, responsiveness, empathy, and reliability dimensions. Smallest mean quality gap, from both groups' viewpoint was found in the reliability dimensions. The largest and smallest differences between students' and teachers' viewpoint were in the responsiveness and tangibility dimensions. A Mann-Whitney $U$ test revealed that significant differences were found between students and faculties in four dimensions of SERVQUAL other than tangibility.

Table II reveals that the majority of both students and teachers declared there was negative quality gap in each of the five dimensions of educational services. The majority of both students and teachers declared there was negative quality gap in each of the five dimensions of educational services. In general, as compared with students, smaller percent of teachers stated there was no quality gap in each of the five dimensions of educational services. Also, higher percent of them stated there was positive quality gap in each of the five dimensions.

The five largest differences between viewpoints of two groups regarding quality gap on statements was observed in: two statements relating to empathy, two statements relating to responsiveness and one statement in the tangibility dimension (Table III). Analyzing these five highest statements indicated that differences between viewpoints of two groups were significant.

The five lowest differences between viewpoints of two groups regarding quality gap on statements was observed in: three statements in the tangibility, one in the reliability and one in the responsiveness dimension (Table IV). Analyzing these five lowest statements indicated that differences between viewpoints of two groups were only in two statements significant.

\section{Discussion and conclusion}

The findings demonstrate that the quality gaps from the viewpoints of both groups in all dimensions were negative (Table I). This indicates that service quality of both groups in all dimensions was generally below expectations. On the other hand, it suggests that educational activities did not manage the factors influencing the quality to meet the expectations of both groups; hence the quality gap was recognized. These results imply that there is room for improvement, and educational service quality in all the five dimensions need to be improved. The largest quality gap was in the responsiveness dimension within the students.

This finding is similar to studies by (Parasuraman et al., 1998; Karydis et al., 2001; Lim \& Tang, 2000), whereas is not consistent with some studies by (Galloway, 1998; Tyran, 2006). Students' views clearly show that responsiveness, empathy and assurance are the three most critical dimensions of educational services. They wanted knowledgeable and enthusiastic individuals who cared about their learning, and helped them to improve their knowledge.

Students expect academic staff to understand their needs, deal with them in a caring fashion, and have knowledge of their teaching subject provision. As it is a prerequisite to having knowledgeable, student-oriented and educational service-minded teachers to serve the students (Ugboma, 2004). Because students considered empathy and responsiveness as critical dimensions, the management needs to recognize the importance of the behavioral aspects of service that were enclosed mainly by these dimensions. Teachers' ability and willingness to satisfy the students educational needs play an important role in determination of the students expectations (Oldfield \& Baron, 2000). 
In this regard, Oldfield \& Baron (2000) believed that showing courtesy and a sincere interest towards students does not cost anything, but can reap great benefits. In many ways, employees may be the only way that a service provider can differentiate itself; for example, in terms of politeness, knowledge and helpfulness while delivering competitive services (Oldfield \& Baron, 2000).

Teachers' results are better. They believe that they are failing to meet expectations to a much smaller degree, since their mean scores are less negative than those of the students. Juwaheer (2004) believes that some expectations are not achievable within the constraints of budget, regulations or other factors). As compared with students, teachers have additional and important knowledge in relation to the provision of the service, and are somewhat aware of such difficulties. This could result in a lower quality gaps views. This study found that from teachers' point of view, the largest quality gap was in the tangible dimension. This was in line with findings of Pariseau and McDaniel (1997), and Galloway (1998). Considering that part of the tangibility dimension is the physical working environment for teachers, it is understandable that their expectations might be higher than those of the students and confirm largest mean quality gap in this dimension.

Although both teachers and students established smallest quality gap in reliability dimension, they differed in the rank ordering of the remaining dimensions. The largest quality gap for students was in responsiveness, which is ranked third by teachers. The second largest mean quality gap for students was in empathy, which is ranked fourth by teachers. In the same manner, the faculties have ranked tangibles first while students have ranked it fourth, though mean quality gap for teachers (-1.14) was smaller than those of students (-1.32) in this dimension. Generally, quality gaps for teachers in all the five dimensions were lower than whatever confirmed by students.

It seems usual that providers (teachers) also recognize somewhat negative mean quality gap, because they also believe that school could provide better services for students. Although differences between students' and teachers' viewpoints regarding quality gap in four dimensions were significant, but it was not significant for tangibility dimension. If students and teachers agree that service quality exceeds, meets or falls below expectations, then there is common ground for continuation or improvement of the level of service quality. But if providers are unaware of a failure to meet expectations, the prognosis for improvement is poor (Pariseau \& McDaniel, 1997). Implementation of internal marketing concept and allocate resources to the training can help the schools to have student-oriented, educational service-minded and knowledgeable teachers to serve the students (Gounaris, 2008; Ahmed \& Rafiq, 2003).

Survey results will add to the body of knowledge in: 1) investigation of educational service quality with internal marketing approach, 2) comparative study of provider (teacher) and customer (provider) of educational services, and 3) extend the literature on service quality in high schools covering the gaps both in the unit of analysis and in the setting. Practically, it can help to determine whether managers need to improve their service levels. Finally, it will help educational management in the process of determining where to allocate scarce resources.

To conclude, in the resource-constrained climate of the high schools in Iran, where students' expectations are continually increasing, there is a recognized need for managers to update and upgrade their services by implementation of internal marketing concept to assure the quality of educational services. On the basis of students' priorities, this research study suggests that there is considerable scope for applying gap analysis methodology in high school contexts.

\section{Limitations}

Since the study was conducted in only one district of Tehran city, it may not be adequate to be generalized. Therefore, similar studies are needed in other settings in Tehran as well as schools of other cities in order to generalize the results. Future research is needed with consideration of the cultural Issues.

\section{Acknowledgement}

The present research was supported by a fellowship allowance offered by the School of Management and Institute of Postgraduate Studies (IPS) at Universiti Sains Malaysia (USM).

\section{References}

Ahmed, P.K., and Rafiq, M. (2003). Internal marketing issues and challenges. European Journal of Marketing, 37(9), 1177-1186.

Berry, L. L., and Parasuraman, A. (1991). Marketing for Services: Competing through Quality. The Free Press, New York, NY.

Berry, L. L. (1988). Service Marketing is different. In marketing management and strategy. Englewood Cliffs(Prentice Hall)(ed. Kotler \& Cox), 278-281. 
Brown, S. P., and Peterson, R. (1993). Antecedents and consequences of salesperson job satisfaction: meta-analysis and causal effects. Journal of Marketing Research, 30(February), 63-77.

Clow, K. E. (1993). Building a Competitive Advantage for Service Firms. International Journal of Service Marketing, 7(1), 22-32.

Donnelly, M., Wisniewski, M., Dalrymple, JF., and Curry, AC. (1995). Measuring service quality in local government: The SERVQUAL approach. Int J Public Sector Manag, 8, 15-20.

Douglas, L., and Connor R. (2003). Attitudes to service quality: The expectation gap. Nutr Food Sci, 33, 165-172.

Farber, B., and Wycoff, J. (1991). Customer service: evolution and revolution. Sales and Marketing Management, 44-51.

Flipo, J. P. (1986). Service firms: interdependence of external and internal marketing strategies. European Journal of Marketing, 20(8), 5-14.

Galloway, L. (1998). Quality perceptions of internal and external customers: A case study in educational administration. TQM Magazine, 10, 20-26.

George, W. R. (1990). Internal marketing and organizational behaviour: a partnership in developing customer-conscious employees at every level. Journal of Business Research, 20(1), 63-71.

Gounaris, S. (2008). Antecedents of internal marketing practice: some preliminary empirical evidence. International Journal of Service Industry Management, 19(3), 400-434.

Gronroos, C. (1982). An applied service marketing theory. European Journal of Marketing, 16(7), 30-41.

Hallowell, R. (1996). The relationships of customer satisfaction, customer loyalty and profitability: An empirical study. Int J Ser Ind Manag, 7, 27-42.

Hays, J., and Hill, A. (2001). A preliminary investigation of the relationships between employee motivation/vision, service learning, and perceived service quality. Journal of Operations Management, 19(3), 335-349.

Hoffman, K. D., and Ingram, T.N. (1992). Service provider job satisfaction and customer-oriented performance. The Journal of Services Marketing, 6(2), 68-78.

Hsieh, L. F., and Lin, L. (2010). A performance evaluation model for international tourist hotels in Taiwan--An application of the relational network DEA. International Journal of Hospitality Management, 29(1), 14-26.

Iwaarden, J., Wiele, T., Ball, L., and Millen, R. (2003). Applying SERVQUAL to web sites: An exploratory study. International Journal of Quality \& Reliability Management, 20(8), 919-935.

Juwaheer, T. (2004). Exploring international tourists' perceptions of hotel operations by using a modified SERVQUAL approach: A case study of Mauritius. Ser Qual Manag, 14, 350-364.

Karydis, A., Komboli, M., and Panis, V. (2001). Expectations and perceptions of Greek patients regarding the quality of dental health services. Int J Qual Health Care, 13, 409-416.

Keaveney, S. (1995). Customer switching behavior in service industries: An exploratory study. J Marketing, 59, 71-82.

Kellogg, DL, Youngdahl, WE and Bowen DE. (1997). On the relationship between customer participation and satisfaction: Two frameworks. Int J Ser Ind Manag, 8, 206-219.

Landrum, H., Prybutok, V. R. Kappelman, L. A., \& Zhang, X. (2008). SERVCESS: A parsimonious instrument to measure service quality and information system success. The Quality Management Journal, 15(3), 17-25.

Lim, PC., and Tang, NK. (2000). A study of patients' expectations and satisfaction in Singapore Hospitals. Int $J$ Health Care Qual Assurance, 13, 290-299.

Lings, I. N. (2000). Internal marketing and supply chain management. Journal of Services Marketing, 14(1), 27-43.

Locke, E. A. (1976). The nature and causes of job satisfaction. Handbook of industrial and organizational psychology. Chicago: Rand McNally (In M.D. Dunnett Ed), 1279-1350.

Meyer, S., and Collier, D. (2001). An empirical test of the causal relationships in the Baldrige health care pilot criteria. Journal of Operations Management, 19(4), 403-425. 
Nunnally, J. (1978). Psychometric theory. Englewood-Cliffs, NJ, McGraw-Hill Book Company.

Oldfield, BM., and Baron S. (2000). Student perceptions of service quality in a UK university business and management faculty. Edu. Qual Assurance, 8, 85-95.

Parasuraman, A., Zeithaml VA., and Berry LL. (1985). A conceptual model of service quality and its implications for future research. J Marketing, 49, 41-50.

Parasuraman, A., Zeithaml, VA., and Berry LL. (1988). SERVQUAL: A multiple item scale for measuring consumer perceptions of service quality. J Retailing, 64, 12-40.

Parasuraman, A., Zeithaml, VA., and Berry, LL. (1994). Alternative scales for measuring service quality: A comparative assessment based on psychometric and diagnostic criteria. $J$ Retailing, 70, 201-230.

Pariseau, SE, and McDaniel, JR. (1997). Assessing service quality in Schools of Business. Int J Qual Reliab Manag, 14, 204-218.

Peeler, G. H. (1996). Selling in the Quality Era. Blackwell Business, USA.

Rafiq, M., and Ahmed, P. (2000). Advances in the internal marketing concept: Definition, synthesis, and extension. Journal of Services Marketing, 14(6), 449-462.

Reichheld, F. F., and Sasser, Jr., W. E. (1990). Zero defections: Quality comes to services. Harvard Business Review, 68(5), 105-111.

Rust, RT. Keiningham, TL. Clemens, S., and Zahorik, AJ. (1999). Return on quality at chase Manhattan Bank. Interfaces, 62-72.

Simon, D., Gomez, M., McLaughlin, E., and Wittink, D. (2009). Employee Attitudes, Customer Satisfaction, and Sales Performance: Assessing the Linkages in US Grocery Stores. Managerial and decision economics, 30, $27-41$.

Soderlund, M. (1998). Customer satisfaction and its consequences on customer behavior revisited: The impact of different levels of satisfaction on word-ofmouth, feedback to the supplier and loyalty. Int J Ser Ind Manag, 9, 169-188.

Soteriou, A., and Chase, R. (1998). Linking the customer contact model to service quality. Journal of Operations Management, 16(4), 495-508.

Stauss, B., and Neuhaus, P. (1997). The qualitative satisfaction model. Int J Ser Ind Manag, 8, 236-249.

Steers, R.M., and Porter, L.W. (1991). Motivation and Work Behavior. McGraw-Hill, New York, NY((5th ed).

Tyran, CK., and Ross, SC. (2006). Service quality expectations and perceptions: Use of the SERVQUAL instrument for requirements analysis. Issues Information Systems, 7, 357-362.

Ugboma, C., Callistus, I., and Ogwude, IC. (2004). Service quality measurements in ports of a developing economy: Nigerian ports survey. Manag Ser Qual, 14, 487-495.

Voss, C., Tsikriktsis, N., Funk, B., Yarrow, D., and Owen, J. (2005). Managerial choice and performance in service management - a comparison of private sector organizations with further education colleges. Journal of Operations Management, 23(2), 179-195.

Yoo, D.K., \& Park, J.A. (2007). Perceived service quality - Analyzing relationships among employees, customers and financial performance. International Journal of Quality \& Reliability Management, 21(9): 908-926.

\section{Tables}

Table I. Students' and teacher' viewpoint about quality gaps in the educational services

\begin{tabular}{|l|l|l|c|c|}
\hline \multirow{2}{*}{ Dimensions } & \multicolumn{2}{|c|}{ Quality gap (M \pm SD) } & \multirow{2}{*}{ Difference } & \multirow{2}{*}{ Mann-Whitney U test } \\
\cline { 2 - 3 } & \multicolumn{2}{|c|}{ Student } & & \\
\hline Responsiveness & $-1.73 \pm 1.11$ & $-0.78 \pm 0.78$ & 0.95 & $<0.0001$ \\
\hline Empathy & $-1.55 \pm 1.10$ & $-0.68 \pm 0.71$ & 0.87 & $<0.0001$ \\
\hline Reliability & $-1.11 \pm 1.00$ & $-0.31 \pm 0.57$ & 0.80 & $<0.0001$ \\
\hline Assurance & $-1.53 \pm 1.10$ & $-0.91 \pm 0.60$ & 0.62 & $<0.0001$ \\
\hline Tangibility & $-1.32 \pm 1.22$ & $-1.14 \pm 0.83$ & 0.18 & Not significant \\
\hline
\end{tabular}


Table II. Frequency / percentage of students and teachers making comments about quality gap

\begin{tabular}{|l|l|l|l|l|l|l|}
\hline \multirow{2}{*}{\multicolumn{1}{|c|}{ Dimensions }} & \multicolumn{2}{|c|}{$\begin{array}{c}\text { Negative quality gap } \\
\text { No/(\%) }\end{array}$} & \multicolumn{2}{c|}{$\begin{array}{c}\text { No quality gap } \\
\text { No/(\%) }\end{array}$} & \multicolumn{2}{c|}{$\begin{array}{c}\text { Positive quality gap } \\
\text { No/(\%) }\end{array}$} \\
\cline { 2 - 8 } & Student & Teacher & Student & Teacher & Student & Teacher \\
\hline Responsiveness & $334(87)$ & $108(77.1)$ & $42(10.9)$ & $10(7.1)$ & $8(2.1)$ & $22(15.7)$ \\
\hline Empathy & $318(82.8)$ & $118(84.3)$ & $53(13.8)$ & $6(4.3)$ & $13(3.4)$ & $16(11.4)$ \\
\hline Reliability & $315(82)$ & $128(91.4)$ & $62(16.2)$ & $4(2.9)$ & $7(1.8)$ & $8(5.7)$ \\
\hline Assurance & $280(72.9)$ & $100(71.4)$ & $87(22.7)$ & $10(7.1)$ & $17(4.4)$ & $30(21.4)$ \\
\hline Tangibility & $275(71.6)$ & $124(88.6)$ & $92(24)$ & $10(7.1)$ & $17(4.4)$ & $6(4.3)$ \\
\hline
\end{tabular}

Table III. The five statements with highest differences

\begin{tabular}{|c|c|c|c|c|}
\hline \multirow{2}{*}{ Statements } & \multicolumn{2}{|c|}{ Quality gap (M \pm SD) } & \multirow{2}{*}{ Difference } & \multirow{2}{*}{$\begin{array}{l}\text { Mann- } \\
\text { Whitney } \\
\text { U test }\end{array}$} \\
\hline & Student & Teacher & & \\
\hline $\begin{array}{l}\text { School teachers take care to understand my request } \\
\text { (Empathy) }\end{array}$ & $-1.82 \pm 1.44$ & $0.09 \pm 0.94$ & 1.91 & $<0.0001$ \\
\hline $\begin{array}{l}\text { School teachers tell me exactly when they are able to } \\
\text { attend to my request (Responsiveness) }\end{array}$ & $-1.76 \pm 1.45$ & $-0.53 \pm 1.18$ & 1.23 & $<0.0001$ \\
\hline School teachers give me prompt service (Tangible) & $-1.98 \pm 1.50$ & $-0.76 \pm 1.10$ & 1.22 & $<0.0001$ \\
\hline $\begin{array}{l}\text { The behavior of school teachers instills confidence in } \\
\text { me (Responsiveness) }\end{array}$ & $-1.60 \pm 1.41$ & $-0.40 \pm 0.93$ & 1.20 & $<0.0001$ \\
\hline $\begin{array}{l}\text { School teachers deal with me in a caring and } \\
\text { courteous manner (Empathy) }\end{array}$ & $-1.06 \pm 1.54$ & $0.06 \pm 1.24$ & 1.12 & $<0.0001$ \\
\hline
\end{tabular}

Table IV. The five statements with lowest differences

\begin{tabular}{|c|c|c|c|c|}
\hline \multirow{2}{*}{ Statements } & \multicolumn{2}{|c|}{ Quality gap $(M \pm S D)$} & \multirow{2}{*}{ Difference } & \multirow{2}{*}{$\begin{array}{l}\text { Mann- } \\
\text { Whitney } \\
\text { U test }\end{array}$} \\
\hline & Student & Teacher & & \\
\hline $\begin{array}{l}\text { The school office is equipped with modern technology } \\
\text { (Tangibles) }\end{array}$ & $-0.86 \pm 1.55$ & $0.67 \pm 1.07$ & 0.19 & $\begin{array}{l}\text { Not } \\
\text { significant }\end{array}$ \\
\hline $\begin{array}{l}\text { School office staff/teachers keep error-free records } \\
\text { (Tangibles) }\end{array}$ & $-0.67 \pm 1.38$ & $-0.47 \pm 1.11$ & 0.20 & $\begin{array}{l}\text { Not } \\
\text { significant }\end{array}$ \\
\hline $\begin{array}{l}\text { The school office staff/teachers dress smartly } \\
\text { (Tangibles) }\end{array}$ & $-0.66 \pm 1.59$ & $-0.90 \pm 0.98$ & 0.24 & 0.02 \\
\hline $\begin{array}{l}\text { The school office has a professional appearance } \\
\text { (Tangible) }\end{array}$ & $-2.08 \pm 1.55$ & $-1.81 \pm 1.40$ & 0.27 & $\begin{array}{l}\text { Not } \\
\text { significant }\end{array}$ \\
\hline $\begin{array}{l}\text { School teachers are always willing to help me } \\
\text { (Reliability }\end{array}$ & $-1.13 \pm 1.23$ & $-0.81 \pm 0.84$ & 0.32 & 0.01 \\
\hline
\end{tabular}

